\title{
Petrographic Characteristics of Manganese Bearing Rocks of Banswara Manganese Ores Belt, District Banswara, Rajasthan (India)
}

\author{
Mohd Shaif1*, F. N. Siddiquie", Subir Mukhopadhyay² \\ ${ }^{1}$ Department of Geology, Aligarh Muslim University (AMU), Aligarh, India \\ ${ }^{2}$ Department of Geological Sciences, Jadavpur University, Kolkata, India \\ Email: *msaif125@gmail.com
}

How to cite this paper: Shaif, M., Siddiquie, F.N. and Mukhopadhyay, S. (2017) Petrographic Characteristics of Manganese Bearing Rocks of Banswara Manganese Ores Belt, District Banswara, Rajasthan (India). Open Journal of Geology, 7, 1047-1062. https://doi.org/10.4236/ojg.2017.77070

Received: June 15, 2017

Accepted: July 24, 2017

Published: July 27, 2017

Copyright $\odot 2017$ by authors and Scientific Research Publishing Inc. This work is licensed under the Creative Commons Attribution International License (CC BY 4.0).

http://creativecommons.org/licenses/by/4.0/

\begin{abstract}
In this paper, we described the petrographical characters of the Mn-bearing rock types outcropping in the Kalakhuta, Ghatia, Gararia, Itala, Wagaicha, Tambesara and Talwara villages of Banswara district. The Mn associated rocks in the study area are phyllite, schist, quartzite and limestone. The mineral assemblage in phyllite formed under greenschist facies metamorphism. Petrographic studies of various phyllite samples also reveal that porphyroblasts of biotite sat in the fine-grained micaceous matrix (Biotite, muscovite, chlorite) along with quartz, opaque and ore minerals. Petrographic studies of schist reveal its formation under prograde metamorphism. Mineral assemblages observed in schist are typical of greenschist to lower amphibolite facies. The various schist samples at places show clusters made up of perfect rhombshaped garnets which suggest the increase in the grade of metamorphism. The quartzites are disposed conformably with the phyllites, and are at times brecciated and re-cemented by secondary chert and manganese. These Mn-bearing quartzites are with sutured/serrated and straight grain boundaries. The quartzite samples are fully composed of quartz showing undulose extinction with subordinate feldspar, micas and carbonatic materials. The petrographic characteristics explain that mostly limestones are the dolomitic composition but some ferruginous varieties are also noticed at places. The purer variety of limestone consists of calcite, dolomite and some magnetite but tremolite, quartz and some minute flakes of biotite also occur in impure variety.
\end{abstract}

\section{Keywords}

Petrographical Characters, Banswara Manganese Ores Belt, Lunavada, Aravalli, Garnet, Modal Analysis 


\section{Introduction}

Banswara district is situated in the southern-most part of Rajasthan. The area is very much renowned by its Bhukia gold deposits. Due to gold, very little attention has been paid towards the other interesting lithological evolutions in the area. The geology of the study area was earlier surveyed by various workers like [1] [2] [3] [4]. The manganese belt occurring in the Banswara district is around $20 \mathrm{~km}$ long with 30 to $70 \mathrm{~m}$ wide from Gararia to Rupakhedi village in Banswara district. The rough estimation about manganese ore reserve is around 2 million tonnes with metal content about $30 \%$ - 45\%. No systematic approach to study the Mn-bearing rocks of Banswara manganese ores belt has been made in an attempt. In this communication we are describing the first detailed petrographic and X-ray diffraction studies of rocks associated with Banswara manganese ores belt, with an aim to understand petrofacies of the study area. Moreover, the petrographic study is a vital tool for providing detailed and relevant information over mineralogy, metamorphism, alteration and paragenetic history of rocks to understand its origin. And these details may be helpful for future studies in the study area to resolve palaeoclimate, geo-tectonic setting and depositional environment.

\section{Geology of the Area under Study}

The regional geology of Banswara district comprises Deccan traps, Aravallis and Pre-Aravalli banded gneissic complex [5] [6] [7] [8] and the manganiferous beds hosted in Aravallis only. The Aravalli group of rocks found in Banswara district brought about by basal quartizitic formation, calcareous facies and argillaceous series of slaty, phyllitic and micaceous sorts with sandy interval. Topographically most of the part of the district shows uneven topography. The high flat hills of Deccan trap are covering the eastern and south-eastern parts of the study area [9].

The Aravalli Supergroup exposed in northwestern India and its basement

Table 1. Stratigraphic succession of study area after [16].

\begin{tabular}{|c|c|c|}
\hline Group & Formation & Lithology \\
\hline \multirow[t]{3}{*}{$\begin{array}{l}\text { Champaner } \\
\text { Group }\end{array}$} & Lambia Formation & Metasubgraywacke, meta-conglomerate, gneiss \\
\hline & $\sim \sim \sim \sim \sim \sim \sim \sim \sim \sim \sim \sim \sim \mathrm{UNCC}$ & 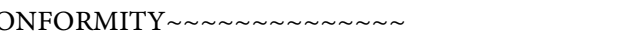 \\
\hline & $\begin{array}{l}\text { Wagidora Formation } \\
\text { forformationFormFormation }\end{array}$ & Metasubgraywacke, mica-schist, pebble and quartzite \\
\hline \multirow[t]{7}{*}{ Lunavada group } & & Phyllite, Felspathised-mica schist \\
\hline & Kalinjara Formation & Quartzite \\
\hline & & Dolomite \\
\hline & & Petromict-meta-conglomerate \\
\hline & & Manganiferous phyllite \\
\hline & $\sim \sim \sim \sim \sim \sim \sim \sim \sim \sim \sim \sim \sim \mathrm{UNCC}$ & 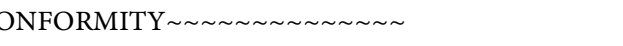 \\
\hline & Synorogen & hic granite \&gneiss \\
\hline
\end{tabular}


commonly referred as the "Banded Gneissic Complex". The Aravalli Supergroup (2500 to $3300 \mathrm{Ma}$ ) overlies the Archaean basement of gneisses and granites (Banded gneissic complex) with a profound unconformity [10]. The maximum $\mathrm{Pb} / \mathrm{Pb}$ isochron age of Aravalli Supergroup is $2200 \mathrm{Ma}$ [11] [12].

The Mn-bearing rocks of study area belongs to Kalinjara formation of Lunavada group which is an important constituent of the southern parts of Aravalli mountain belt (SAMB), lies under Aravalli Supergroup (Table 1). The lunavada group is one of the younger group of Aravalli super group [13] [14] [15].

The Lunavada Group has been subdivided into the Kalinjara, Wagidora, Bhawanpura, Chandanwara, Bhukia and Kadana Formations [16].

The Kalinjara formation comprises dominantly phyllite, feldspathic micaschist, meta-subgreywacke, quartzite, dolomite and manganiferous phyllite as shown in Table 1. The geological map of the region prepared by [17] helps to illustrate a very complex geometry of superposed folding exhibited by thin bands of quartzite embedded in thick beds of phyllite [18]. The rocks of the Lunavada region have undergone metamorphism up to lower amphibolite facies [19]. Various prominent structures like ptygmatic folding, lineation and joint sets are present in the Mn associated rocks of the study area. The rocks have taken for petrographic studies typically exposed at Banswara district $\left(23^{\circ} 15^{\prime}-23^{\circ} 20^{\prime} \mathrm{N}\right.$ to $74^{\circ} 15^{\prime}-74^{\circ} 25^{\prime} \mathrm{E}$ ) (Figure 1). The manganese ores and its bearing rocks broadly strike between N-S and NNW-SSE with absolutely steep or vertical dips.
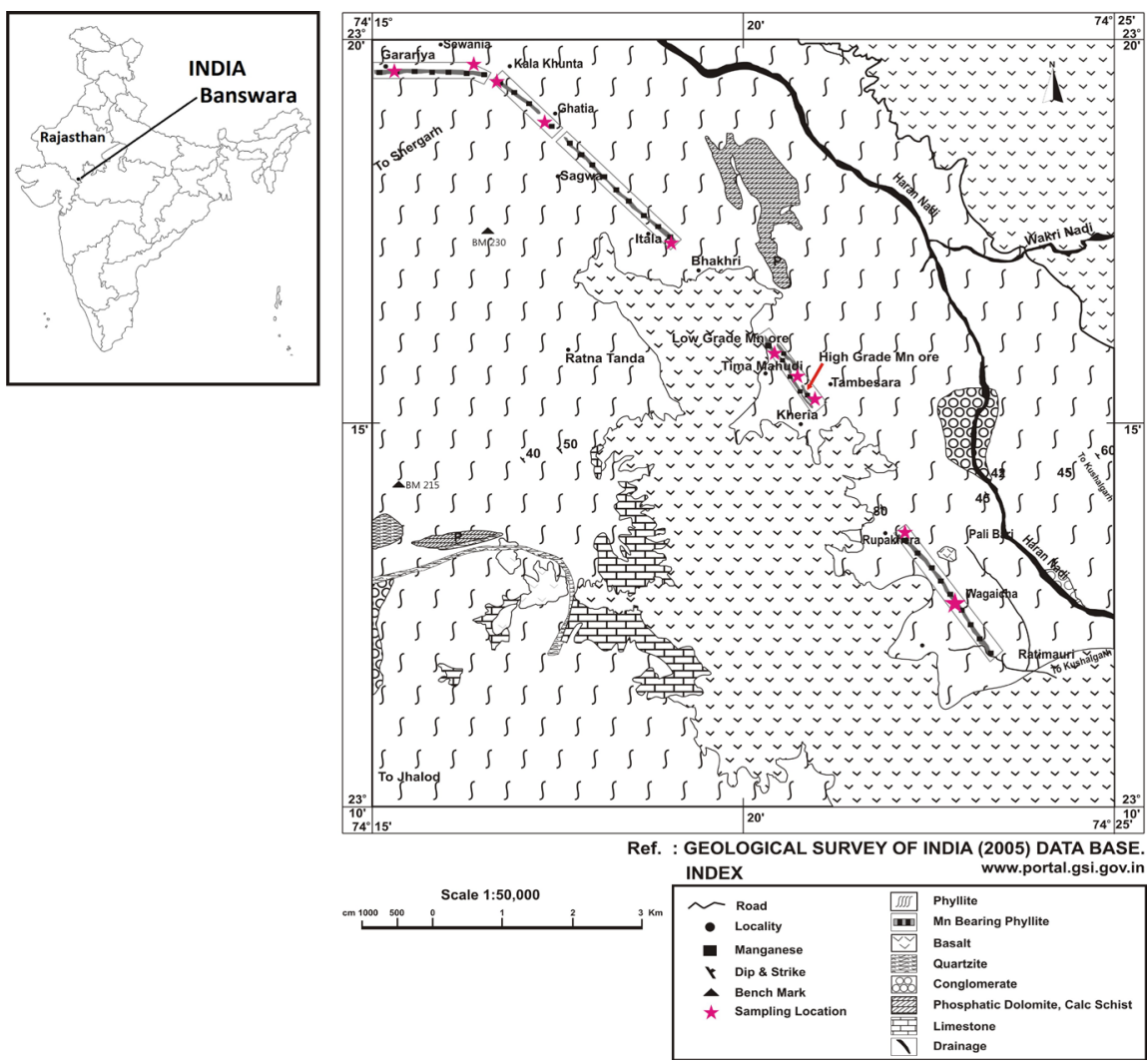

Figure 1. A generalised geological map of Banswara Manganese ores belt, Banswara district Rajasthan (After GSI 2005). 


\section{Methodology Adopted}

Besides the collected samples, fifteen fresh and unweathered rock samples were selected for petrographic studies under transmitted light (Olympus BX51) and X-ray diffraction analysis of samples by Xpert Pro Panalytical. Modal Analysis was carried out for rock types to estimate the approximate percentage of various minerals by using Gazzi-Dickinson method.

\section{Petrography}

\subsection{Phyllite}

The phyllite is the dominant rock types of Banswara manganese ores belt. The rocks of the argillaceous composition are represented by phyllites [20]. Megascopically the associated phyllite rock of study area is fine-grained, light grey in color with various hardness and fissility. They contain minute garnet crystals. On the other hand, manganiferous fine-grained phyllite with various shades of grey, brown and red has also been reported. Dendritic pattern and crenulations are the prominent features seen by naked eye.

\subsection{Siliceous Phyllite}

The rock is composed of fine-grained muscovite and chlorite as abundant minerals associated with enough amount of quartz. The garnet, magnetite, hematite, feldspar and opaque are accessory minerals. Muscovite laths showing nonpleochroic with moderate relief and low birefringence. At some places, chlorite grains are coalesced with each other indicating that they have suffered directed pressure under metamorphism. Chlorite shows its characteristic greenish pleochroism with low relief. The quartz grains are xenoblastic and show undulose extinction with the encrustation of manganese ores. Garnet crystals are in perfect rhombohedral shaped with several encrustation of opaque minerals (Figure $2(1)$ ). The rock is ferruginous at places due to hematite. The mineral assemblages explain that phyllite is the siliceous type which is a common rock type in Lunavada and Kadana areas.

\subsection{Manganiferous Phyllite}

This rock shows the dominance of muscovite flakes along with chlorite. Quartz layers are sandwiched between muscovite and dark opaque mineral layer (Figure 2(3)). All minerals are parallel to foliation plane (Figure 2(3)). The quartz grain layer is parallel to the foliation plane and micaceous minerals. The inclusion of opaque minerals is hosted within quartz grains. Another thin section of rock is fine to medium grained exhibit schistose structure (Figure 2(4)). It is mainly composed lapidoblast of muscovite, biotite and coarse-grained quartz. Muscovite flakes uniformly cleaved with perfect preferred orientation and form the schistosity. The chlorite mineral is rare or absent. Quartz is usually xenoblastic to subhedral and shows undulose extinction. 


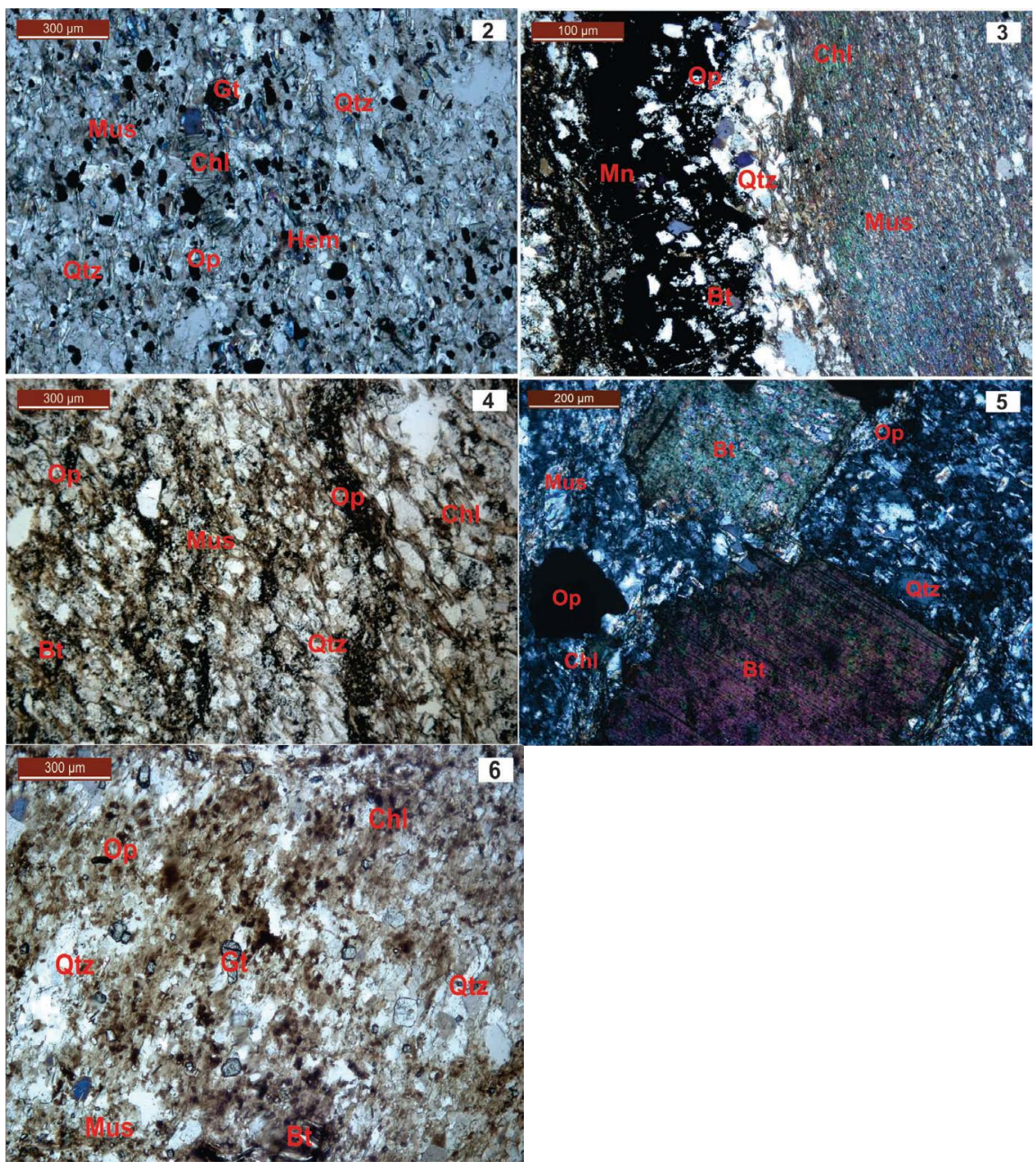

Figure 2. (2) Abundant quartz with deposition of manganese ores in scattered form within siliceous phyllite; (3) Minerals aligned perfectly along the foliation in manganiferous phyllite; (4) Muscovite (Mus) and chlorite (Chl) show schistosity in manganiferous phyllite; (5) Mineral boundary relationship between lapidoblasts of Biotite $(\mathrm{Bt})$ with other minerals in Chlorite-biotite Phyllite; (6) Biotite(Bt) alteration into chlorite (Chl) in muscovite phyllite, Banswara manganese ore belt. Banswara district, (Rajasthan). (Under Crossed Polars).

\subsection{Chlorite-Biotite Phyllite}

The rock is rich in perfect lapidoblastic biotite grains set in the fine-grained micaceous matrix (Figure 2(5)). Biotite shows strong pleochroism (brown to yellow) with high relief. In plain polarized light biotite displays perfect cleavage in one direction. The mineral boundary relation of biotite with other minerals (Figure 2(5)) suggests that the biotite grains are formed at the later stage. Chlorite is characterized by light greenish color with weak birefringence. The rock is also composed of xenoblastic medium grained quartz and uniformly cleaved muscovite flakes. The accessory minerals are feldspar, tourmaline and opaque ore minerals.

\subsection{Muscovite Phyllite}

The rock is fine to medium grained, essentially composed of muscovite and 
chlorite as dominant mineral, with quartz, biotite, garnet, feldspar and opaques as accessory minerals. The chlorite mineral clearly showing its diagnostic green to brownish color with low relief in plane polarized light. Most of the chlorite occurs in lens-shaped form. The biotite alteration in chlorite clearly noticed in the lower part of section (Figure 2(6)). The quartz grains are xenoblastic with of micaceous and opaque minerals. The garnet crystals occurring in perfect rhombohedral shape with fracture filled with manganese ores and opaque inclusions. In all rock samples, Mn ores associated with encrustation or in inclusion occur in various minerals. Beside this, Mn ores deposited along the boundaries of various minerals grains. Petrographic studies revealing mineral assemblages of different samples are listed in (Table 2). The two-theta position of different minerals has given in (Figures 3(7)-(9)).
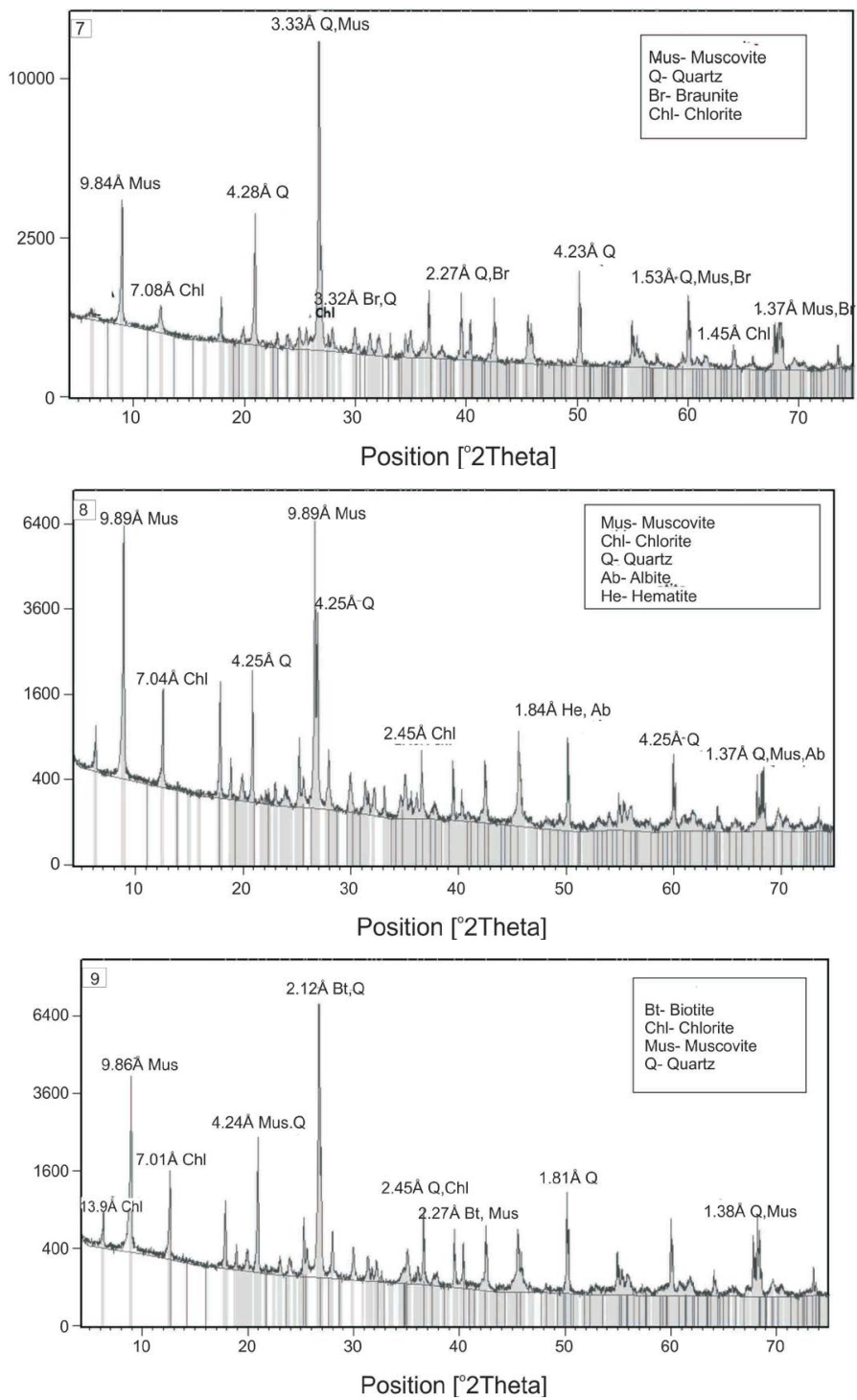

Figure 3. (7) $2 \theta$ positions of muscovite, chlorite, quartz and braunite, in siliceous phyllite; (8) $2 \theta$ positions of muscovite, chlorite, quartz, albite and hematite, in manganiferous phyllite; (9) $2 \theta$ positions of muscovite, chlorite, biotite and quartz, in chlorite-biotite phyllite. Banswara district (Rajasthan). 
Table 2. Mineral assemblages in Phyllite rocks of study area.

\begin{tabular}{ccc}
\hline $\begin{array}{c}\text { Type of } \\
\text { Sediment }\end{array}$ & Metamorphic equivalent & Mineral Assembladge \\
\hline Pelites & Siliceous Phyllite & Muscovite + Chlorite + Quartz + Garnet + Opaque \\
Pelites & Manganiferous phyllite & Muscovite + Chlorite + Quartz \pm Biotite + Opaque \\
Pelites & Muscovite phyllite: & Muscovite + Chlorite + Quartz \pm Biotite + Garnet + Opaque \\
Pelites & $\begin{array}{c}\text { Chlorite-Biotite } \\
\text { phyllite: }\end{array}$ & Chlorite + Biotite + Muscovite + Quartz + Opaque \\
\hline
\end{tabular}

\subsection{Schist}

The mica schist and phyllite are predominant rocks in the study area and form about $70 \%$ of the rocks of this belt, where only the top portion of this formation is mineralized [21]. Bedding, crenulation and foliation like features are commonly noticed at places. Intercalations of quartzite are common. Under the thin section, schist samples are medium to coarse grained and composed of quartz, muscovite, chlorite, biotite, garnet, alkali feldspar, plagioclase, opaques, fluorapatite and ore minerals. At some places, biotite occurs as large porphyroblast with rugged termination [22]. Quartz grain occurs in coarser and finer form. Garnet occurs as porphyroblast and in clusters. Schistose texture well defined by muscovite, chlorite and biotite flakes. The mineral assemblages of different samples are listed in (Table 3).

\subsection{Garnetiferous-Mica Schist}

Garnetiferous-mica schist is medium-grained, showing clusters of garnet crystals and consists mainly of muscovite as a dominant mineral with quartz, biotite, chlorite, feldspar and opaque as accessory minerals. The microfolded manganese ores bands also occur (Figure 4(10)). The texture is medium grained and. The minerals muscovite and biotite shows the different generation of foliations [23] explained that garnetiferous biotite schist having minerals of more than one generation and two set of foliation S1 and S2 predominantly developed in the region lying south of Lunavada tract.

The encrustation of opaques within quartz, garnet and other minerals are common. Garnet is generally abundant constituents of this group of rocks. The garnet crystals are of perfect rhombohedral in shape (Figure 4(11)). The garnet crystal also found in embedded form over quartz at various places. XRD reveals the garnet crystals belong to $\mathrm{Mg}-\mathrm{Cr}$ and $\mathrm{Ca}-\mathrm{Al}$-rich composition. Quartz grains encrusted with the inclusion of minute garnet and secondary quartz itself. Biotite and chlorite are brownish and greenish respectively.

\subsection{Quartz-Mica Schist}

Quartz-mica schist is composed of medium to coarse-grained quartz, and muscovite as essential minerals. The muscovite shows well developed schistose texture. The lamellaes of muscovite shows moderate relief with perfect one set cleavage. Under cross polar muscovite shows high birefringence. The quartz grains are 
Table 3. Mineral assembladges in Schist rocks of study area.

\begin{tabular}{ccc}
\hline $\begin{array}{c}\text { Type of } \\
\text { Sediment }\end{array}$ & Metamorphic equivalent & Mineral Assembladge \\
\hline Pelites & Garnetiferous-micaschist & Garnet + Muscovite + Chlorite \pm Biotite + Quartz + Opaque. \\
Pelites & Quartz-micaschist & Quartz + Muscovite + Chlorite \pm Biotite + Garnet + Opaque \\
Pelites & Muscovite-chloriteschist & Muscovite + Chlorite \pm Biotite + Quartz + Opaque. \\
\hline
\end{tabular}
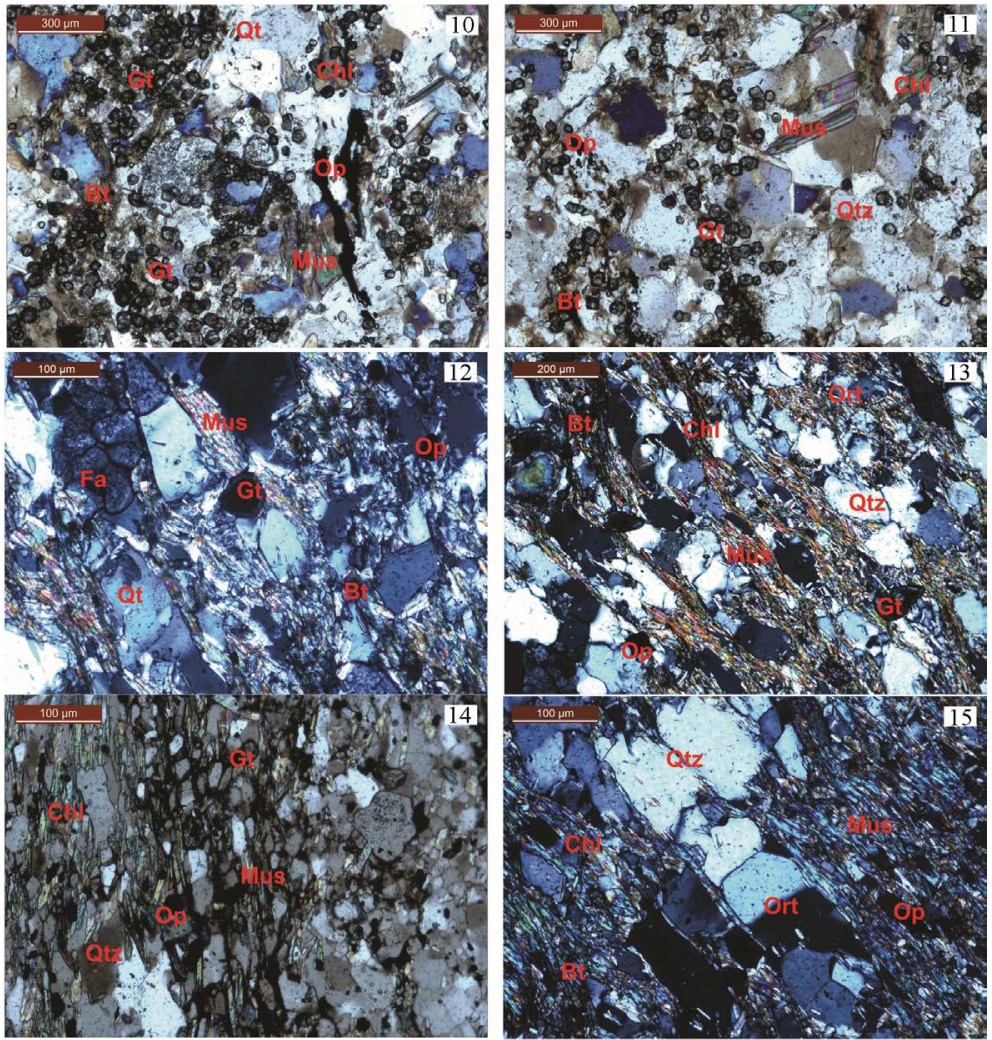

Figure 4. (10) (11) Clusters of perfectly rhombohedral shaped garnet (Gt) and microfold bands of manganese ore in Garnetiferous Mica Schist; (12) (13) showing rims of porphyroblasts of garnet (Gt); (14) Mn-ore minerals along the mineral boundaries of uniformly oriented muscovite (Mus) and chlorite (Chl); (15) Quartz grain layer defining foliation in muscovite-chlorite schist, Banswara manganese ore belt, Banswara district, (RajasthanBanswara manganese ore belt, Banswara district, (Rajasthan).(Under crossed polar).

arranged parallel to muscovite and biotite lapidoblasts. The quartz grains show undulose extinction. The accessory minerals are biotite, chlorite, alkali feldspar, garnet and opaque minerals. The garnet rims are present with the encrustation of opaques in various minerals (Figure 4(12) and Figure 4(13)). Fluorapatite and tourmaline are also present.

\subsection{Muscovite-Chlorite Schist}

Muscovite-chlorite schist is composed of dominant mineral as muscovite and chlorite with quartz, biotite, feldspar and opaques as accessory minerals. The muscovite and chlorite flakes uniformly oriented with the deposition of dark color minerals along with their boundaries (Figure 4(14)). Perfect elongated 
crystals of chlorite are showing moderate relief. Under cross polar chlorite shows low birefringence with first order interference color. Muscovite occurs as lapidoblasts with basal cleavage. Quartz is usually xenoblastic and highly fractured with some crystals show undulose extinction. The garnet crystals are rounded in shape and partially filled with opaque minerals. In another rock section, quartz grains arrange themselves parallel to foliation plane and sandwiched from both sides by mica minerals (Figure 4(15)). There is a marked gradation of quartz and micaceous minerals [24]. Mineral assemblages observed in schist are typical of greenschist to lower amphibolite facies.

Mn ore deposited along the minerals boundaries and in embedded form. And two theta position of various minerals has given in (Figures 5(16)-(18)).
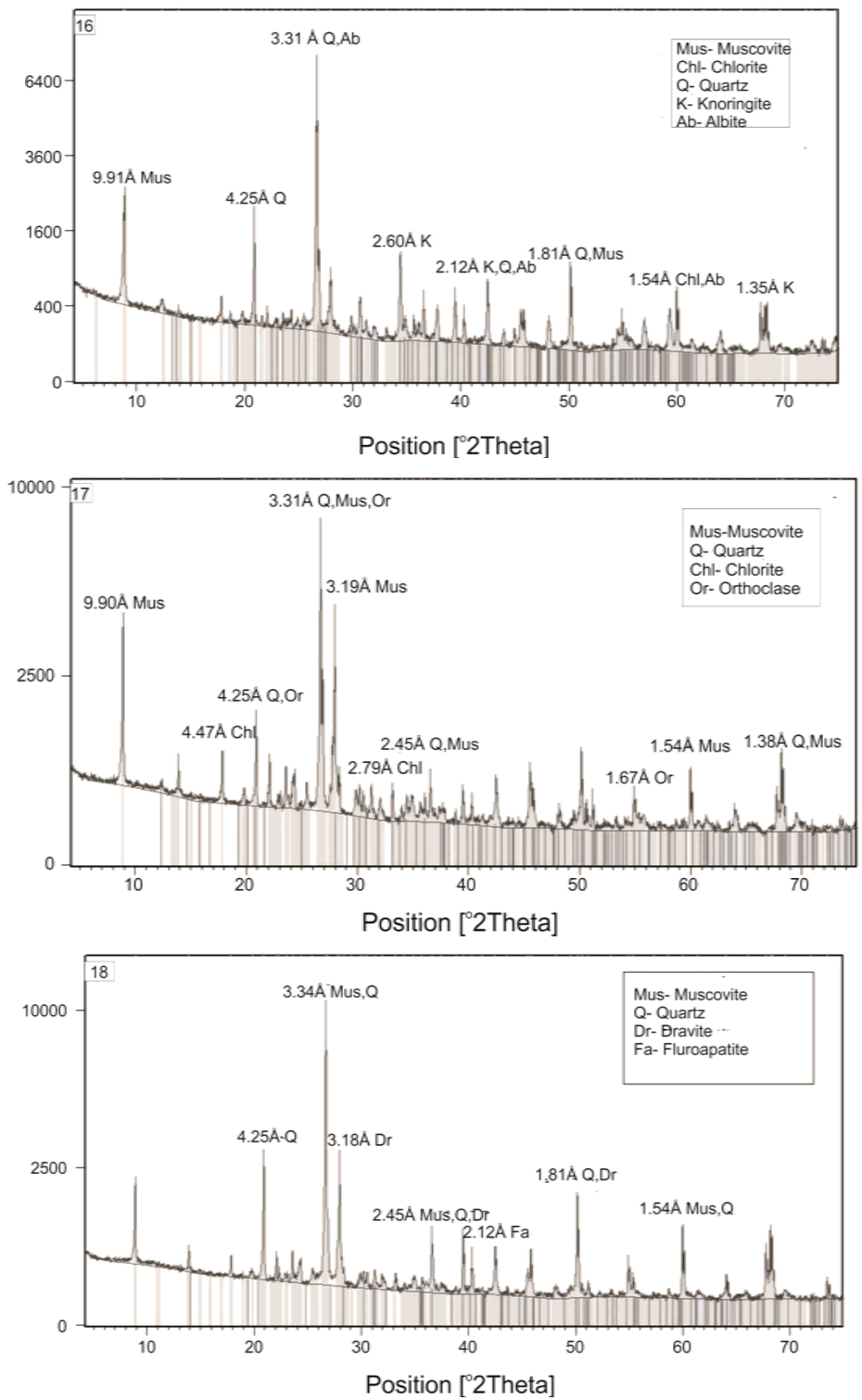

Figure 5. (16) $2 \theta$ positions of muscovite, chlorite, quartz, albite and garnet, in Garnetiferous mica schist; (17) $2 \theta$ positions of muscovite, quartz, fluroapatite and dravite, in Muscovite-chlorite schist; (18) $2 \theta$ positions of muscovite, chlorite, orthoclase and quartz, in Quartz mica schist. 


\subsection{Limestone}

The limestone samples were collected from Talwara village. Besides these deposits, there are numerous minor occurrences of limestones between Kalinjra and Pali Chhoti localities in Banswara district. Some of the limestone beds are effectively exposed in the west of Talwara and striking NNW-SSW.

The limestone is thick bedded and crystalline. The bedding of limestones is in conformity with phyllites and quartzites. Various irregular joints, fissures, cavernous pockets are characteristic features of limestone in Talwara. The manganese ores are distributed very irregularly in the limestone.

The petrographic studies reveal that mostly limestones are dolomitic in composition [25] but some ferruginous varieties are also noticed at places. Dolomitic limestone is composed of calcite, dolomite and some magnetite (Table 4). The rock is medium to coarse grained and shows mosaic structure (Figure 6(19)) [25]. Minor amount of quartz, tremolite, and minute flakes of biotite occur in impure varieties (Figure 6(20)). The ferruginous variety of limestone contains disseminations of hematite and limonite. The other impurities are in form of

Table 4. Mineral assemblages in Limestone rocks of study area.

\begin{tabular}{ccc}
\hline Type of Sediment & Rock Type & Mineral Assembladge \\
\hline & & Calcite + Dolomite + Magnetite + Quartz + Chert + Opaque. \\
Calcareous & Limestone & Calcite + Dolomite + Quartz + Hematite + Opaque. \\
& & Calcite + Dolomite + Tremolite + Biotite + Quartz + Opaque. \\
\hline
\end{tabular}
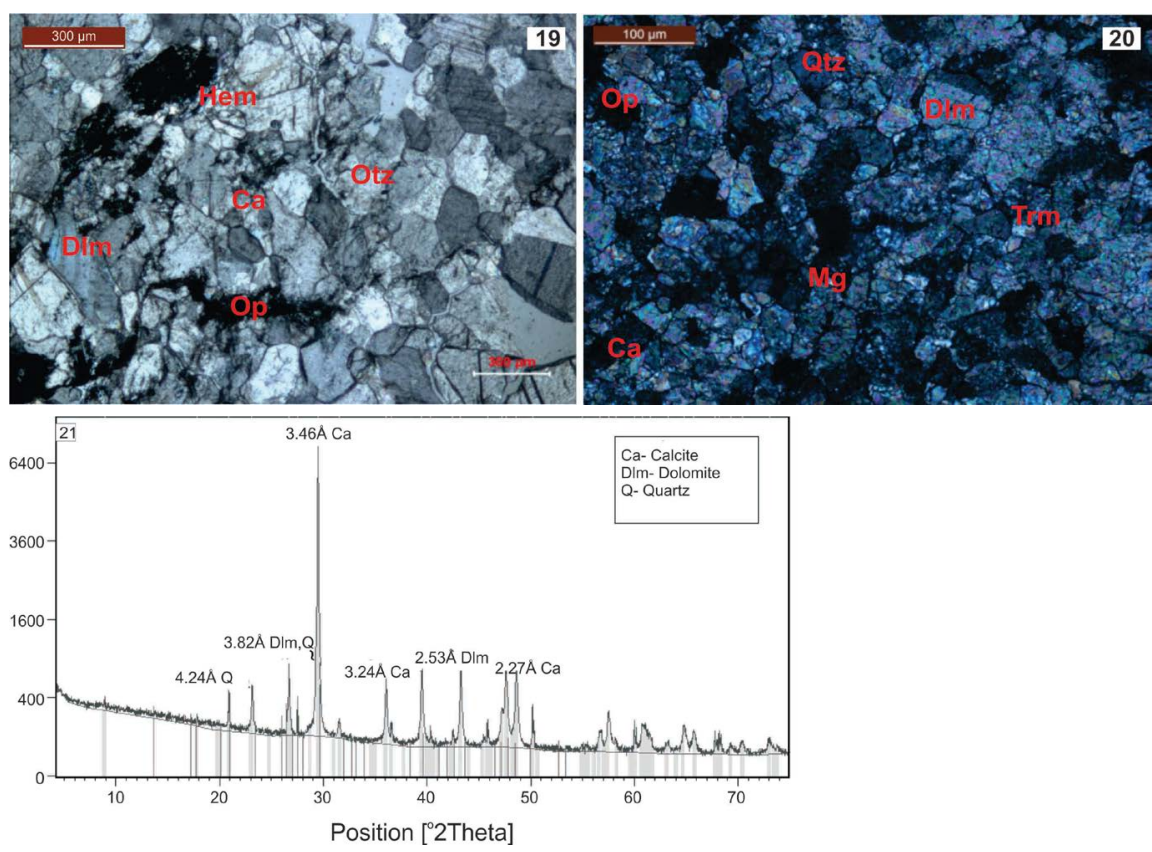

Figure 6. (19) The rock having the mosaic structure with sub graphic intergrowth of quartz (Q) in Mn-bearing dolomitic limestone; (20) Dark colour impure varieties of limestone having tremolite, quartz, biotite(Under crossed polar). Banswara manganese ore belt, Banswara district, (Rajasthan); (21) $2 \theta$ positions of calcite, dolomite and quartz, in Mn-limestone. 
chert, flint and iron-bearing minerals like hematite. Due to impurities, the colour of limestone changes from white to redbrick and greyish. The two-theta position of various minerals has given in (Figure 6(21)).

\subsection{Quartzite}

The quartzite outcrop extends over miles within the area from Gararia to Ratimauri with roughly NW-SE direction and contains thin bands of manganese ore. The quartzites are disposed conformably with the phyllite and are at times brecciated and later re-cemented by secondary chert and manganese [26]. The various samples of quartzite rocks collected at different places in the study area from Gararia to Ratimauri villages and near Talwara localities of Banswara district.

The different rock samples are composed predominantly of quartz with subordinate mica, feldspar, opaques and impurities of hematite (Figure $7(22)$ ). Sericitization and calcareous materials also noticed in some thin sections (Figure 7(23)). Mostly they are compact and crystallised. The quartz grains are idioblastic to sub-idioblastic type. The rounded to subrounded shape of fragments may be due to mutual attrition during brecciation [27]. The petrographic study reveals that quartz grains are medium to coarse grained, low in relief and birefringence showing granoblastic texture (Figure 7(24) and Figure 7(25)). Feldspar like orthoclase and plagioclase show polysynthetic and lamellar twinning (Figure 7(24) and Figure 7(25)). Manganese ore is occasionally associated with orthoclase as small inclusions [28]. The quartz inclusion in larger grains of quartz shows optical homogeneity [29]. All fragments of quartzite thin sections

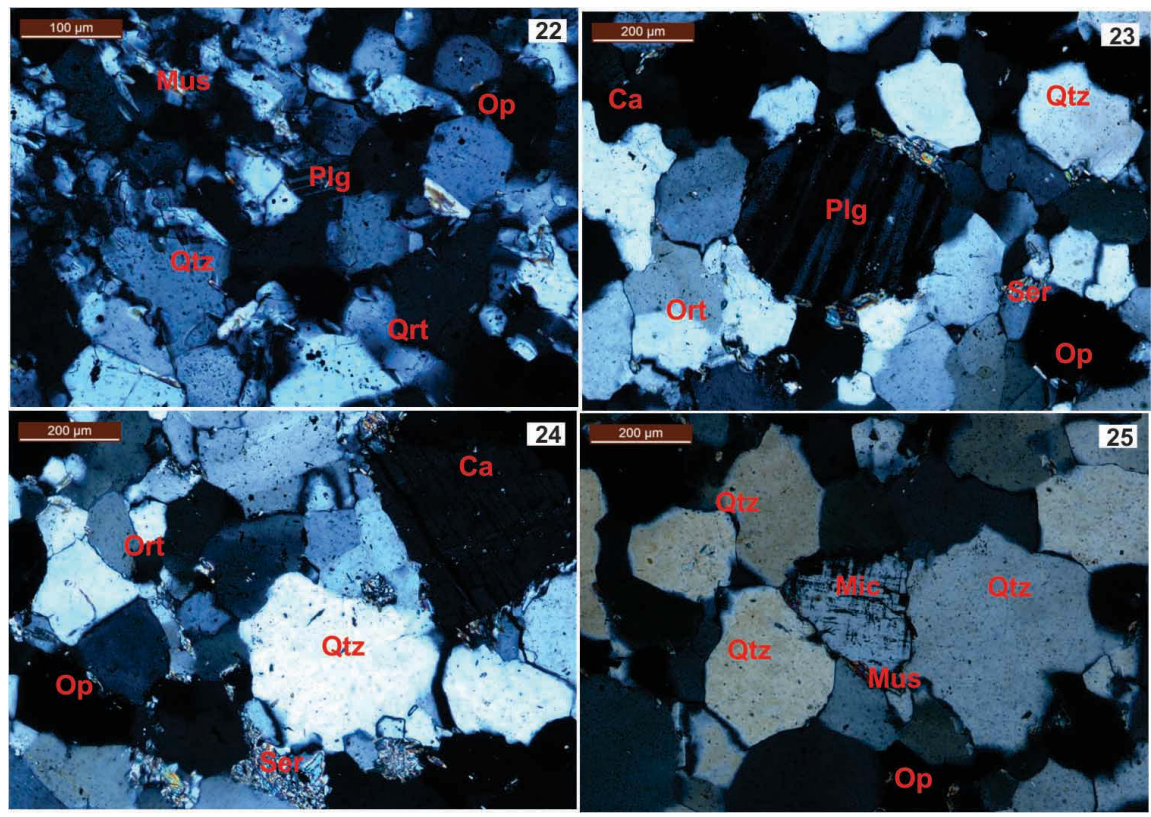

Figure 7. (22) Encrustation of manganese ore with impurities of iron; (23) Granoblastic texture with twinned porphyroblast of plagioclase (Plg); (24) Quartz showing straight grain boundaries and sericitization at places with the encrustation of manganese ore; (25) Quartz showing quartz grains with serrated/sutured grain boundaries. Banswara manganese ore belt, Banswara district, (Rajasthan). (Under crossed polar). 
near Talwara village shows undulatory extinction and contain fractured filled with sericite. Quartz crystal shows straight grain boundaries with sharp extinction. According to [30] and [31], the presence of serrated/sutured grain boundaries indicates that the rock underwent grain boundary migration recrystallization (GBMR). The mineral assemblage and two theta position of different samples of Quartzite rock is given in (Table 5) and (Figure 8(26) and Figure 8(27)) respectively.

Table 5. Mineral assembladges in Quartzite rocks of study area.

\begin{tabular}{ccc}
\hline $\begin{array}{c}\text { Type of } \\
\text { Sediment }\end{array}$ & $\begin{array}{c}\text { Metamorphic } \\
\text { equivalent }\end{array}$ & Mineral Assembladge \\
\hline & & Quartz + Plagioclase + Orthoclase + Sericite + + Calcite + Opaque. \\
Quartz + Orthoclase + Sericite Calcite + Opaque.
\end{tabular}
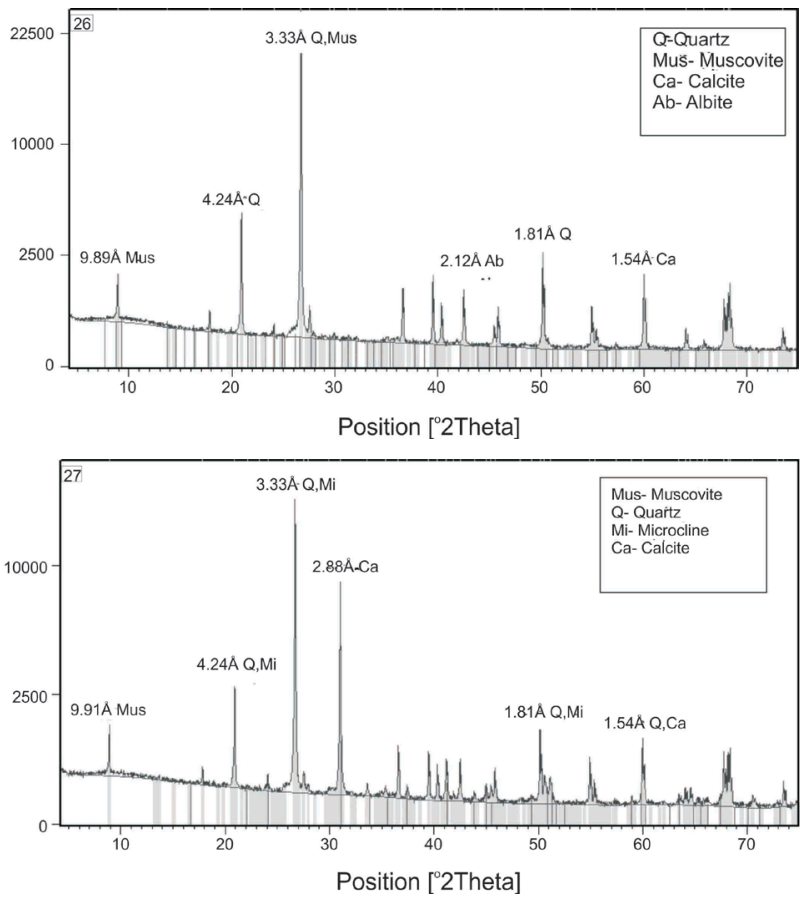

Figure 8. (26) $2 \theta$ positions of quartz, calcite and albite, in Mn-Quartzite; (27) Showing $2 \theta$ positions of quartz, muscovite, calcite and microcline, in Mn-Quartzite, Banswara district (Rajasthan).

\section{Conclusion}

Petrographic studies and modal analysis (Table 6) suggest that the different rock types in the study area are Siliceous phyllite, Manganiferous phyllite, Muscovite phyllite, Chlorite-biotite phyllite, Garnetiferous-mica schist, Quartz-mica schist, Muscovite-chlorite schist, Limestone and Quartzite. In the light of above fact, it appears that regional metamorphism has played an important role in metamorphism of pelitic-psammitic and calcareous sediments which are the prominent Mn comprising rocks of the study area and finally metamorphosed to present 
Table 6. Mineral percentage in Mn bearing rocks of study area.

\begin{tabular}{ccccccccc}
\hline \multirow{2}{*}{ Mineral } & \multicolumn{7}{c}{ Mn } & \multicolumn{7}{c}{ Siliceous } & \multicolumn{7}{c}{ (hlorite Garnetiferous } & Quartz \\
phyllite & phyllite & biotite & mica & mica & chlorite & Limestone Quartzite \\
phyllite & schist & schist & schist & & \\
\hline Qtz & 22 & 39 & 24 & 23 & 39 & 21 & 5 & 80 \\
Mus & 31 & 31 & 12 & 34 & 28 & 41 & 1 & 2 \\
Bio & 3 & 4 & 29 & 3 & 5 & 2 & 1 & 1 \\
Chl & 14 & 7 & 22 & 7 & 7 & 20 & $\times$ & 1 \\
Feld & 2 & 2 & 1 & 3 & 4 & 1 & $\times$ & 4 \\
Gt & 3 & 2 & 3 & 21 & 4 & 4 & $\times$ & $\times$ \\
Op & 20 & 15 & 9 & 8 & 11 & 9 & 9 & 8 \\
Mg & 2 & $\times$ & $\times$ & $\times$ & $\times$ & $\times$ & 3 & $\times$ \\
He & 3 & $\times$ & $\times$ & $\times$ & $\times$ & $\times$ & 2 & 2 \\
Fa & $\times$ & $\times$ & $\times$ & 1 & 1 & 2 & 0 & $\times$ \\
Ca & $\times$ & $\times$ & $\times$ & $\times$ & $\times$ & $\times$ & 56 & 2 \\
Do & $\times$ & $\times$ & $\times$ & $\times$ & $\times$ & $\times$ & 22 & $\times$ \\
Total & 100 & 100 & 100 & 100 & 100 & 100 & 100 & 100 \\
\hline
\end{tabular}

Legend-Minerals in (\%) Mus = Muscovite, $\mathrm{Qtz}=\mathrm{Quartz}, \mathrm{Bio}=$ Biotite, $\mathrm{Chl}=$ Chlorite, $\mathrm{Gt}=$ Garnet, $\mathrm{Op}=$ Opaque, Feld $=$ Feldspar, $\mathrm{Mg}=$ Magnetite, $\mathrm{He}=$ Hematite $\mathrm{Ca}=$ Calcite, $\mathrm{Do}=$ Dolomite, $\mathrm{x}=$ None .

day rock types viz, phyllite, schist and quartzite. As the rocks of the study area have undergone metamorphism up to lower amphibolite facies, the deformation took place at relatively low temperature. The phyllite and schist samples mineral assemblages fall in greenschist to lower amphibolite facies and formed by prograde metamorphism of Aravalli metasediments. Quartzite is non-foliated and both medium to coarse grained (Granoblastic). The quartzites disposed conformably with phyllite and narrowly brecciated with re-cemented by secondary chert and manganese. The calcareous rock shows dolomitic composition with some impure ferruginous varieties. Thin sections studies suggest manganese ores in phyllite and schist rocks deposited along the mineral boundaries and the foliation plane. They are also found in form of dark colour patches in some thin sections. In garnet and quartz, manganese is found in both ways as inclusion or encrustation over them. In limestone manganese mineralisation in sporadic forms etc. In quartzite, manganese ores associated in form of patches and encrustation as well.

\section{Acknowledgements}

The authors are grateful to Prof. Abu Talib, Chairman Department of Geology, AMU Aligarh, Mr Syed Mujtaba, Superintendent Geologist, Geological Survey of India, Faridabad for XRD and their valuable guidance providing research facilities. Anonymous reviewer for suggesting necessary corrections in the manuscript. Mohd Shaif is grateful to UGC for financial support in the form of a fellowship (MANF). 


\section{References}

[1] Crookshank, H. (1946) Report on Recent Tour to Rajputana. (G.S.I Unpublished Progress Report for the Field Season 1946-47)

http://www.portal.gsi.gov.in/gsiDoc/fspReports/WRO/Pre-1950/WRO_13678_1945 _1946_REPORT_1.pdf

[2] Sinha, A.P. (1980) A Report on Manganese Investigation (Garariya-Ratimauri Manganese Belt), Banswara District, Rajasthan. (G.S.I Unpublished Progress Report for the Field Season 1980-81)

http://www.portal.gsi.gov.in/gsiDoc/fspReports/WRO/1980-1985/WRO_12750_198 0_1981_REPORT_1.pdf

[3] Babel, G.L. (1985) Report on Investigation Carried Out for Assessment of Manganese Deposits in Tambesra-Tima Mahuri Area, Tehsil Kushalgarh, District Banswara. Rp No. 1547, Year 1985-86, Department of Mines \& Geology, Rajasthan. http://www.dmgoms.mines.rajasthan.gov.in/DMG/Geo_Report_PRfirstSite.jsp

[4] Heron, A.M. (1953) Geology of Central Rajasthan. Mem. 79, Geological Survey of India, 339.

[5] Gupta, B.C. (1934) The Geology of Central Mewar. Memoir of Geological Society of India, 65, 107-168.

[6] Joshi, S.V. and Jangid, O.P. (2008) Review for Manganese, Calcite and High Grade Limestone near Villages Tambesara, Chikli, Lasodla and Kala Khunta Tehsil Khushalgarh District Banswara. Rp. No. 2236, Year 2008-09, Department of Mines \& Geology, Rajasthan.

http://www.dmgoms.mines.rajasthan.gov.in/DMG/Geo_Report_PRfirstSite.jsp

[7] Joshi, S.V. and Jangid, O.P. (2009) Regional Mineral Survey for Manganese, Limestone, Iron Ore near Village Jalampura, Maska, Mahuri, Kasarwari and Pandawal Chotta Tehsil Kushalgarh District Banawara . Rp. No 2237, Year 2009-10, Department of Mines \& Geology, Rajasthan.

http://www.dmgoms.mines.rajasthan.gov.in/DMG/Geo_Report_PRfirstSite.jsp

[8] Sukhwal, K.L. and Dixit, R.K. (2000) Regional Mineral Survey for Limestone and Industrial Minerals like Manganese N/V Moian, Jaspura, Rangi, Agoria etc., Tehsil Kushalgarh, District Banswara. Rp. No. 1657, Year 2001-02, Department of Mines \& Geology, Rajasthan.

http://www.dmgoms.mines.rajasthan.gov.in/DMG/Geo_Report_PRfirstSite.jsp

[9] Khan, K.F. and Samsuddin, K. (2016) Petro-Mineralogical Studies of Phosphorite Deposit of Sallopat Block of Banswara District, Rajasthan, India. World Academy of Science, Engineering and Technology. International Journal of Environmental, Chemical, Ecological, Geological and Geophysical Engineering, 10, 666-673.

[10] Roy, A.B. and Purohit, R. (2015) Lithostratigraphic, Geochronological and Depositional Framework of the Precambrian Basins of the Aravalli Mountain and Adjoining Areas, Rajasthan, India. Geological Society London, Memoirs, 43, 55-65.

[11] Schleicher, H., Tod, W., Viladkar, S.G. and Schimdt, F. (1997) Pb-Pb Age Determination of Newania and Savattur Carbonatites of India Evidence of Multiple Stage Histories. Chemical Geology, 140, 261-270. https://doi.org/10.1016/S0009-2541(97)00022-3

[12] Deb, M. and Thorpe, R.I. (2004) Geochronological Constraints in the Precambrian Geology of Rajasthan and Their Metallogenic Implications. In: Deb, M. and Goodfellow, W.D. (Eds.), Sediment-hosted Lead-Zinc Sulphide Deposits, Narosa, New Delhi, 246-263.

[13] Gupta, S.N., Arora, Y.K., Mathur, R.K., Iqballuddin, Prasad, B., Sahai, T.N. and 
Sharma, S.B. (1980) Lithostratigraphic Map of Aravalli Region Southern Rajasthan and Northern Gujrat. Published Geological Survey of India, Hyderabad.

[14] Gupta, S.N., Mathur, R.K. and Arora, Y.K. (1992) Lithostratigraphy of Proterozoic rocks of Rajasthan and Gujarat-A Review Record. Geological Survey of India, 115, 63-85.

[15] Gupta, S.N., Arora, Y.K., Mathur, R.K., Iqbaluddin, Prasad, B., Sahai, T.N. and Sharma, S.B. (1995) Geological Map of the Precambrians of the Aravalli Region, Southern Rajasthan and Northeastern Gujarat, India. Geological Survey of India Publication.

[16] Gupta, S.N., Arora, Y.K., Mathur, R.K., Iqballuddin, Prasad, B., Sahai, T.N. and Sharma, S.B. (1997) The Precambrian Geology of the Aravalli Region, Southern Rajasthan and North-Eastern Gujarat. Memoir Geological Survey of India, 123, 59-61.

[17] Gupta, B.C. and Mukherjee, P.N. (1934) The Geology of Gujarat and Southern Rajputana. Record Geological Survey of India, 73, pt-2.

[18] Roy, A.B. and Jakhar, S.R. (2002) Geology of Rajasthan (Northwest India): Precambrian to Recent. Scientific Publishers, India, 75-154.

[19] Mamtani, M.A. (1998) Deformational Mechanisms of the Lunavada Pre Cambrian Rocks Panchmahal District Gujarat. Department of Geology, Maharaja Sayajirao University of Baroda. http://hdl.handle.net/10603/58797

[20] Gadhadharan, A. (1978) Report on the Systematic Mapping in Parts of Banswara, Udaipur and Chittorgarh Districts, Rajasthan. Geological Survey of India, Unpublished Progress Report for the Field Season 1977-78.

http://www.portal.gsi.gov.in/gsiDoc/fspReports/WRO/1975-1980/WRO_11200_197 7_1978_REPORT_1.pdf

[21] Mukherjee, K.K. and Kapoor, S.C. (1960) Report on Detailed Geological Mapping of the Banswara Manganese Ore Belt, Banswara District, Rajasthan. Geological Survey of India, Unpublished Progress Report for the Field Season 1959-60. http://www.portal.gsi.gov.in/gsiDoc/fspReports/WRO/1955-1960/WRO_2134_1959 _1960_REPORT_1.pdf

[22] Iqballuddin and Negi, R.S. (1971) Systematic Geological Mapping in Parts of Banswara \& Udaipur Districts, Rajasthan. Geological Survey of India, Unpublished Progress Report for the Field Season 1971-72.

http://www.portal.gsi.gov.in/gsiDoc/fspReports/WRO/1970-1975/WRO_11307_197 1_1972_REPORT_1.pdf

[23] Mamtani, M.A., Merh, S.S., Karanth, R.V. and Greiling, R.O. (2000) Time Relationship between Metamorphism and Deformation in the Proterozoic Rocks of Lunavada Region, Southern Aravalli Mountain Belt (India). Journal of Asian Earth Sciences, 19, 195-205.

[24] Ro, P.K. (1985) Report on the Systematic Mapping in Parts of Banswara Districts, Rajasthan. Geological Survey of India, Unpublished Progress Report for the Field Season 1983-84.

http://www.portal.gsi.gov.in/gsiDoc/fspReports/WRO/1980-1985/WRO_23740_198 3_1984_REPORT_1.pdf

[25] Rasul, S.H. and Khan, M.A. (1963) The Geology of the Manganese Ore Deposits of Talwara, District Banswara, Rajasthan. Proceedings of the Indian Academy of Sciences, 57, 190-198.

[26] Roy, B.C. (1957) The Manganese Ore Deposits in Udaipur and Banswara Districts, Rajasthan. Bulletin Geological Survey of India, Series A-Economic Geology 14, 131. 
[27] Harker, A. (1939) Metamorphism. Methuen and Co., 166.

[28] Siddiquie, F.N. (2010) Petrographical Characters of Some Important Host Rocks in Vizianagarm Manganese Ores Belt (A.P.) India. University of Mauritious Research Journal, 16. https://www.ajol.info/index.php/umrj/article/download/130802/120375

[29] Garg, R.L. (1973) Report on Systematic Geological Mapping around Banswara District, Rajasthan. Geological Survey of India, Unpublished Progress Report for the Field Season 1973-74.

http://www.portal.gsi.gov.in/gsiDoc/fspReports/WRO/1970-1975/WRO_4447_1973 1974_REPORT_1.pdf

[30] Urai, J., Means, W.D. and Lister, G.S. (1986) Dynamic Recrystallization of Minerals. American Geophysical Union Monograph, 36, 161-200.

[31] Passchier, C.W. and Trouw, R.A.J. (1996) Microtectonics. Springer-Verlag, Heidelberg. In: Mamtani, M.A., Merh, S.S., Karanth, R. V. and Greiling, R.O., Eds. (2000), Time Relationship between Metamorphism and Deformation in the Proterozoic Rocks of Lunavada Region, Southern Aravalli Mountain Belt (India), Journal of Asian Earth Sciences, 195-205.

Submit or recommend next manuscript to SCIRP and we will provide best service for you:

Accepting pre-submission inquiries through Email, Facebook, LinkedIn, Twitter, etc. A wide selection of journals (inclusive of 9 subjects, more than 200 journals)

Providing 24-hour high-quality service

User-friendly online submission system

Fair and swift peer-review system

Efficient typesetting and proofreading procedure

Display of the result of downloads and visits, as well as the number of cited articles

Maximum dissemination of your research work

Submit your manuscript at: http://papersubmission.scirp.org/

Or contactojg@scirp.org 